\title{
Analisis Makna Implisit dan Eksplisit pada Bahasa Batak Toba dan Bahasa Indonesia
}

\author{
Yusniaty Galingging, \\ Fakultas Sastra, Universitas Kristen Indonesia \\ yusniaty galingging@yahoo.com
}

\begin{abstract}
Abstrak
Setiap bahasa bersifat unik. Bahasa mempunyai caranya masing-masing untuk menyampaikan maksudnya. Bahasa Indonesia mempunyai caranya sendiri yang berbeda dari bahasa Batak, meskipun kedua bahasa ini berada pada wilayah yang sama, yaitu teritori Indonesia. Kedua bahasa ini mempunyai karakteristik masing-masing dalam hal menyampaikan pemikirannya. Makna dalam suatu bahasa dapat dinyatakan secara implisit dan secara eksplisit. Mengimplisitkan makna, maksudnya adalah tidak menyatakan makna tertentu secara jelas, baik melalui kosa kata atau gramatika bahasa itu akan tetapi makna itu dipahami oleh pembaca. Makna yang dieksplisitkan, yaitu makna yang dinyatakan dengan kosa kata atau dengan struktur bahasa itu sendiri. Suatu makna dinyatakan secara eksplisit atau implisit tergantung pada konteks atau ketersediaan kosa kata pada sebuah bahasa. Menyatakan makna secara eksplisit dapat menghindarkan ambiguitas, ketidakjelasan dan kesalahpahaman. Akan tetapi mengekpresikan makna secara eksplisit berulang-ulang dapat menyebabkan sepertinya membodohi pembaca, seakan pembaca tidak mengetahui topik yang sedang dibicarakan atau juga dapat membuat tulisan itu membosankan. Data yang digunakan pada kajian ini adalah Patik Ni Debata Nasampului Dohot Lapatanna untuk data bahasa Batak dan Dasa Titah untuk bahasa Indonesia. Pada kajian ini dapat dilihat bahwa Bahasa Batak pada umumnya mengeksplisitkan maknanya dibanding dengan bahasa Indonesia. Tujuan dari kajian ini adalah untuk memberi gambaran karakteristik bahasa Batak dan Bahasa Indonesia khususnya dalam hal mengekspresikan maknanya.
\end{abstract}

Kata Kunci: Implisit, eksplisit, padanan kata, karakteristik bahasa

\begin{abstract}
Every language is unique. Language has a specific way to state its idea. The Indonesian language has its way that differs from the Batak language in conveying their meaning, eventhough both belong to the same region, that is Indonesian territory. These two languages have their specific characteristics in expressing their thoughts. Meaning in a language can be defined implicitly and explicitly. To explain a meaning implicitly means that the meaning is expressed without using a particular word and a language structure, but the reader understands it. To tell a meaning explicitly implies that the meanings are expressed by using a word or by the language's structure. To convey the meaning explicitly or implicitly depends on the
\end{abstract}


context or by some cirstumstaces and the lexicon's availability in a language. To express a meaning explicitly may avoid ambiguity, vagueness, and misunderstanding. But, describing the meaning explicitly all the time may cause ignorant, as if other people know nothing about the topic of the discussion. The data used is taken from Patik Ni Debata Nasampului Dohot Lapatanna for Batak Language and Dasa Titah for the Indonesian language. This writing shows that the Batak language uses straightforward way more in comparison to the Indonesian language. This study aims to draw a characteristic of the Batak language and Indonesian language, especially in expressing their meaning.

Key words : Implicit, Explicit, equivalence, language characteristics

\section{Pendahuluan}

Menerjemah memerlukan keterampilan berbahasa yang baik yang meliputi keterampilan berbahasa sumber dan berbahasa sasaran. Bagi orang yang menguasai kedua bahasa dengan baik, tantangan mendapatkan kata yang sepadan bukanlah masalah besar. Namun, penerjemah perlu mewaspadai adanya perbedaan cara pengekspresian makna pada tiap bahasa di antaranya makna implisit dan eksplisit dalam suatu bahasa. Mengimplisitkan makna dapat terjadi oleh karena kosa kata yang tersedia pada bahasa itu sendiri dan mengeksplisitkan makna dapat disebabkan oleh tidak tersedianya kosa kata yang sama, untuk maksud yang sama sehingga harus diekspresikan dengan menggunakan bentuk leksikon tertentu. Selain itu, mengeksplisitkan makna dapat juga untuk maksud memberi penekanan makna tertentu dan terkadang juga untuk menghindarkan keambiguan atau kesalahpahaman. Dan semua hal ini dilakukan untuk mendapatkan impresi yang sama dari kedua bahasa.

Sebagaimana yang dikatakan Vinay dan Jean Daebernet :

But translators may also notice gaps, or "lacunae", in the target language (TL) which must be filled by corresponding elements, so that the overall impression is the same for the two messages. It may, however, also happen that, because of structural or metalinguistic differences, certain stylistic effects cannot be transposed into the TL without upsetting the syntactic order, or even the lexis. (Vinay and Jean Darbelnet, 2000: 84)

Penerjemah harus memperhatikan adanya jurang antara bahasa sumber dan bahasa sasaran yang memerlukan elemen yang dapat menghubungkannya, yang kemudian akan memberikan impresi yang sama pada kedua bahasa. Oleh karena itu dapat terjadi perbedaan struktur atau metalinguistik, gaya pengekspresian tanpa melakukan perubahab urutan bahkan kosa katanya. (Vinay and Jean Darbelnet, 2000: 84) 


\section{Sumber Data}

Data yang digunakan sebagai bahan perbandingan keimplisitan dan keekplisitan pada kajian ini adalah Patik Ni Debata Nasampului Dohot Lapatanna untuk data bahasa Batak dan Dasa Titah untuk bahasa Indonesia. Pasal-pasal ini dianggap cukup untuk mewakili kajian makna implisit dan eksplisit dalam bahasa Batak Toba dan Bahasa Indonesia. Kajian lebih dalam tentunya dapat dilakukan secara lengkap di masa yang akan datang, atau dapat diteruskan oleh siapa saja yang tertarik melihat unsur implisit dan eksplisit pada kedua bahasa ini.

Pemilihan data yang digunakan adalah karena Bahasa Batak yang ada pada Patik Na Sampulu adalah Bahasa Batak (BB) yang digunakan secara meluas pada kegiatan kerohanian di gereja HKBP bahkan Patik $\mathrm{Na}$ Sampulu ini diucapkan pada setiap kebaktian Minggu. Sudah tentu bahasa Batak yang digunakan ini adalah Bahasa Batak yang dapat dipahami oleh penutur Bahasa Batak. Dasa Titah yang digunakan sebagai padanan dari BB ini dapat juga diambil dari Dasa Titah yang digunakan pada masyarakat HKBP juga. Masyarakat HKBP tentunya juga adalah penutur bahasa Indonesia, oleh karena itu Dasa Titah inipun dapat dipahami secara utuh oleh masyarakat Batak. Pilihan terhadap data ini dilakukan agar kedua sumber data yang digunakan memang benar dipahami oleh penutur BB dan BI.

\section{Tujuan Penulisan}

Tujuan penulisan adalah untuk melihat karakter Bahasa Batak dan Bahasa Indonesia dalam hal menyampaikan maknanya. Apakah Bahasa Batak yang lebih sering mengeksplisitkan maknanya atau mengimplisitkan maknanya, demikian juga dengan bahasa indonesia. Pemahaman akan karakter kedua bahasa ini tentunya dapat memberikan gambaran mengenai karakter makna kosa kata kedua bahasa kepada penerjemah ketika berhadapan dengan kedua bahasa ini. Dengan demikian upaya untuk mendapatkan kosa kata yang sepadan dalam penerjemahan dapat dicapai.

Selain itu tulisan ini juga memperlihatkan bahwa setiap bahasa itu bersifat arbitrer, atau bersifat unik. Bahasa selalu mampu menyampaikan makna yang sama dengan caranya sendiri apakah secara implisit atau secara eksplisit melalui kosa kata atau gramatika yang dimilikinya.

\section{Masyarakat Batak}

Suku Batak merupakan salah satu suku bangsa terbesar di Indonesia, berdasarkan sensus dari Badan Pusat Satistik pada tahun 2010. Suku Batak merupakan sebuah tema kolektif untuk Angkola, Karo, Mandailing, Pakpak/Dairi, Simalungun, dan Toba. Sering orang menganggap suku Batak hanya merujuk pada suku Toba. Pada umumnya 
suku Batak mendiami sebagian besar wilayah Sumatera Utara. (https://id.wikipedia.org/wiki/Suku_Batak). Sebelum masa kedatangan Belanda, suku-suku yang termasuk dalam suku Batak mengakui dirinya sebagai Batak, dan Belandalah yang telah membuat terpisahnya kelompok-kelompok tersebut. (https://id.wikipedia.org/wiki/Suku_Batak)

Orang Batak adalah penutur bahasa Austronesia, meski tidak diketahui bilamana nenek moyang suku Batak bermukim di Tapanuli dan Sumatera Timur pada awalnya. (https://id.wikipedia.org/wiki/Suku_Batak). Bahasa Batak kaya akan Puisi-puisi, Pepatah dan Pribahasa yang berisikan kata-kata bijak. (https://id.wikipedia.org/wiki/Suku_Batak)

Agama dari masyarakat Batak yang paling banyak penganutnya adalah agama Kristen, katolik, islam dan Parmalim. Jumlah yang terbesar di antaranya adalah beragama kristen. Masyarakat yang beragama Kristen paling banyak adalah jemaat gereja HKBP, yaitu Huria Kristen Batak Protestan. Gereja HKBP adalah gereja yang berpusat di Sipoholon, Tarutung yang telah berdiri pada tahun 1917. Pada tahun 1935 orang Batak yang sudah dibaptis sudah mencapai 450.000 orang. (https://id.wikipedia.org/wiki/Suku_Batak). Saat ini penganut HKBP telah memiliki jemaat sekitar 6.5 juta anggota di seluruh Indonesia. (https://id.wikipedia.org/wiki/Huria_Kristen_Batak_Protestan)

\section{Implisit dan Eksplisit}

Menurut Larson (1984) mengatakan menerjemahkan itu adalah mengkomunikasikan makna yang sama pada bahasa kedua sebagaimana yang dikomunikasikan dalam bahasa pertama. Tidak semua makna dinyatakan secara jelas, yaitu dengan menggunakan bentuk-bentuk bahasa sumber. Oleh karena itu menemukan adanya informasi yang eksplisit dan implisit merupakan hal yang turut dipertimbangkan dalam menemukan makna dalam penerjemahan. Dalam melakukan hal ini penerjemah harus mewaspadai adanya informasi yang eksplisit dan implisit.

Translation, then, is communicating the same meaning in a second language as was communicated in the first. Not all the of the meaning which is being communicated is stated overtly in the form of the source language text. Discovering the meaning of the text to be translated includes consideration of both explicit and implicit information. Larson; 1984: 41.

Informasi eksplisit adalah infromasi yang dinyatakan secara jelas dengan menggunakan bentuk-bentuk linguistik, sedangkan informasi implisit adalah adanya makna yang tidak diwakili oleh leksikon atau gramatika suatu bahasa. Seperti halnya dalam Bahasa Inggris she dan he yang dalam Bahasa Indonesia (BI) sepadan dengan kata 'dia'. Kata she dan he bahasa Inggris secara eksplisit mengandung makna jender. She 
jendernya perempuan dan he berjender laki-laki. Dalam $\mathrm{BI}$ she dan he keduanya sepadan dengan kata 'dia'. Kata 'dia' pada BI jendernya bersifat implisit karena kata 'dia' dapat merujuk pada yang berjender laki-laki maupun perempuan. She/he dan 'dia' sama-sama adalah pronomina ketiga tunggal, namun di dalam B.Ing jendernya eksplisit dalam kosa kata itu sendiri dan di dalam BI jendernya implisit, tidak dapat diketahui hanya melalui kosa kata itu sendiri tetapi diketahui dari rujukan kata 'dia' itu.

Demikian juga halnya di dalam BB ada ditemukan kata 'natoras' yang sepadan dengan 'orang tua' dalam bahasa Indonesia (BI). Ketika menerjemahkan kata ini, penerjemah dapat menggunakan kata 'orang tua' atau juga 'bapak dan ibu'. Komponen makna dari kata orang tua adalah 'bapak dan ibu' maka dengan menggunakan kosa kata ini tentunya makna 'natoras' tetap sebagaimana yang dimaksudkan bahasa sumber. Yang jadi masalah adalah, apakah sipenerjemah menggunakan kata 'orang tua' atau 'bapak dan ibu', ini adalah pilihan penerjemah. Ketika penerjemah menggunakan 'bapak dan ibu' maka dapat dikatakan penerjemah mengeskplisitkan makna yang terdapat pada kata 'natoras', tetapi apabila menggunakan kata 'orang tua' penerjemah dalam hal ini mengimplisitkan komponen makna kata tersebut. Alasan untuk mengeksplisitkan atau mengimplisitkan suatu makna tentunya dilatari oleh beberapa hal, di antaranya kosa kata dari bahasa itu sendiri atau gramatika bahasa itu yang memaksakan demikian atau juga pilihan sipenerjemah untuk memberikan penekankan makna yang ingin ditonjolkan penerjemah. Pada contoh bahasa Inggris di atas, padanan kata 'dia' Bl di dalam B.Ing haruslah mengeksplisitkan jender pada B.Ing walaupun dalam BI tidak demikian. Dalam B.Ing tidak ada pronomina ketiga tunggal yang tidak menyatakan jender. Oleh karena itu dalam hal ini dikatakan kosa kata yang tersedia yang wajibkan untuk mengeksplisitkan atau mengimplisitkan makna tertentu.

Pada situasi yang berbeda, ada kalanya masalah eksplisit atau implisit adalah pilihan penerjemah. Maksudnya, ketika BSu menggunakan kosa kata yang mengimplisitkan maknanya, walaupun ada leksikon yang juga mengimplisitkan makna tersebut pada BSanya, namun penerjemah memilih menggunakan kosa kata yang mengeksplisitkan maknanya. Alasan terhadap pilihan ini adalah ada beberapa hal, yaitu untuk membuat kalimat lebih bervariasi atau bermaksud untuk memberi penekanan pada makna tertentu.

\section{Analisis}

Analisis data dibagi menjadi dua kelompok. Yang pertama adalah kata-kata yang ditemukan berulang-ulang, yaitu kata ndang jadi dan unang. Kedua kata ini dipadankan ke BI dengan 'jangan'. Selain kedua kata di atas, data lainnya akan diuraikan masing-masing sesuai dengan temuan makna yang diimplisitkan atau dieksplisitkan, baik pada BB demikian juga pada BI. 


\section{Analisis Kata Ndang jadi dan Unang \\ a. Ndang jadi (BB) 'Jangan' (BI)}

\section{Data 1:}

a. BB: Ndang jadi marangkup Ahu bahenonmu Debatam.

$\mathrm{BI}$ : Jangan ada padamu allah lain di hadapan-Ku. (Hukum kesatu)

b. BB: Ndang jadi ganaonmu jala ndang jadi sumanonmu manang aha na di banua ginjang dohot na di banuatonga on...

$\mathrm{BI}$ : Jangan membuat bagimu patung yang menyerupai apapun yang ada di langit di atas... (Hukum kedua)

c. BB: Ndang jadi dohonon goar ni Debata...

BI: Jangan menyebut nama TUHAN, Allahmu... (Hukum ketiga)

d. BB: Ndang jadi ho mangula anggo di sadari i...

$\mathrm{BI}$ : jangan melakukan sesuatu pekerjaan... (Hukum keempat)

\section{Analisis Data 1:}

Secara literal kata ndang jadi dalam BB adalah 'jangan pernah'. Kata ini merupakan bentuk larangan yang sangat tegas. Seperti pada kalimat 'Jangan pernah datang ke tempat ini lagi'. Maksud dari kalimat tersebut menunjukkan adanya larangan yang keras untuk tidak datang ke tempat tersebut oleh karena adanya hal-hal yang sangat tidak diinginkan di tempat itu. Pada data BI ditemukan kata ndang jadi dipadankan dengan kata 'jangan'. Apabila kita bandingkan kata 'jangan' digunakan pada kalimat di atas 'jangan datang ke tempat ini lagi' dengan 'jangan pernah datang ke tempat ini lagi' pada contoh ini jelas dapat kita rasakan perbedaan ketegasan larangan tersebut. Penggunaan kosa kata ini dapat dilihat pada kalimat Ndang jadi marangkup... 'Jangan ada padamu'; Ndang jadi ganaonmu... 'Jangan membuat bagimu dan pada 'Ndang jadi dohonon... 'Jangan menyebut'.

Sementara itu pada BB kata ndang jadi yang diikuti dengan berbagai verba, seperti ndang jadi marangkup 'jangan pernah membuat yang sepertiku'; ndang jadi ganaonmu 'jangan pernah engkau membentuk yang sepertiku' ; ndang jadi dohonon, 'jangan pernah engkau menyebut'; ndang jadi sumanonmu 'jangan pernah engkau menyamakanku' dapat dikatakan ketegasan akan larangan dinyatakan secara eksplisit. Dikatakan demkian karena pada BB kata larangan 'jangan' dikuti dengan kata 'pernah' yang berarti larangan yang tidak boleh dilakukan sama sekali. Kata 'jangan' dalam BI sepadan juga dengan 'unang' pada BB. Kalau pada konteks di atas kata 'jangan' $\mathrm{BI}$ dipadankan dengan unang maka ketegasan untuk tidak melakukan larangan itu menjadi tidak setegas kalau menggunakan ndang jadi. Ketegasan ini semakin jelas oleh karena larangan ini, yaitu yang menggunakan kata ndang jadi semuanya berkaitan dengan hubungan dengan Tuhan, yaitu kita dilarang menyebut nama 
Tuhan, dan juga membuat tiruannya. Hal ini tentunya tidak ada tawar menawar maka oleh sebab itu larangan itu sangat tegas dalam BB.

Data 2: Unang (BB) 'Jangan' (BI)

a. BB: Unang ho mamunu

$\mathrm{BI}$ : Jangan membunuh.( Hukum Keenam)

b. BB: Unang ho mangalangkup

$\mathrm{BI}$ : Jangan berzinah (Hukum Ketujuh)

c. BB: Unang ho manangko

$\mathrm{BI}$ : Jangan mencuri (Hukum Kedelapan)

d. BB: Unang ho olo manghatindanghon hata na so tutu maralohon dongan jolma.

$\mathrm{BI}$ : Jangan mengucapkan saksi dusta tentang sesamamu. (Hukum Kesembilan)

\section{Analisis Data 2:}

Pada data 2 adalah kata unang pada BB yang dalam BI menggunakan kata 'jangan'. Hal ini dapat dilihat pada Patik Paonompon sampai Patik Pasiahon, yaitu Dasa Titah keenam hingga 'hukum ke sembilan'. Unang ho mamunu 'Jangan membunuh'; Unang ho mangalangkup 'Jangan berzinah' ; Unang ho manangko 'Jangan mencuri'. Keeksplisitan BB yang dapat dilihat pada bentuk larangan ini adalah hadirnya persona kedua ho 'engkau, kamu' sebagai objek dari larangan itu pada BB. Pada BI persona kedua ini diimplisitkan. Bentuk kalimat yang digunakan pada $\mathrm{Bl}$ adalah kalimat perintah. Pada kalimat perintah memang lawan bicara atau persona kedua itu dapat dilesapkan saja, atau diimplisitkan.

Jadi, pernyataan di atas dapat pada BB padanannya adalah Unang ho mamunu 'Janganlah engkau membunuh' ; Unang ho mangalangkup 'Janganlah engkau berzinah' ; Unang ho manangko 'Janganlah engkau mencuri'. Munculnya persona kedua pada BB dalam hal ini merupakan bentuk yang natural pada struktur BB. Tanpa persona kedua atau objek dari larangan ini, maka kalimat tersebut menjadi tidak natural dalam BB, seperti *unang mamunu, *unang manangko, *unang mangalangkup. Persona kedua pada BB dapat dihilangkan hanya apabila objek yang dilarang itu disebutkan. Misalnya pada kalimat unang mamunu jolma 'jangan membunuh manusia'; unang manangko manuk 'jangan mencuri ayam. Dari uraian ini dapat dilihat bahwa pengeksplisitan persona kedua pada BB disebabkan oleh karakter atau struktur BB itu sendiri.

Dalam BI mengeksplisitkan persona kedua pada konteks kalimat ini sebenarnya tetap natural. Seperti 'janganlah kamu mencuri; janganlah kamu berzinah'. Namun, tanpa menghadirkan persona kedua setelah bentuk larangan, kalimat tersebut sudah dipahami sepenuhnya. Penerjemah tidak mengeksplisitkan persona kedua ini pada BI bisa saja 
untuk alasan keekonomisan, oleh karena pesan utamanya telah disampaikan.

\section{Analisis Hukum Pertama}

Pada bagian ini akan dianalisis setiap data yang ditemukan mengandung pengeksplisitan maupun pengimplisitan makna dari setiap hukum dari data yang digunakan.

\section{Data 1:}

BB: Ahu do Jahowa DebataM, ninna Debatanta. Ndang jadi marangkup Ahu bahenonmu Debatam. (Patik Parjolo)

$\mathrm{BI}$ : 'Jangan ada padamu allah lain di hadapan-Ku'. (Hukum kesatu)

\section{Analisis Data 1}

Data $1 \mathrm{BB}$ apabila dinyatakan dalam BI secara literal adalah 'Akulah Tuhan Allahmu, kata Tuhan kita'. Jangan pernah kamu membuat yang seperti aku, Tuhan Allahmu'. Pada BI maksud yang sama ini dinyatakan dengan satu kalimat 'Jangan ada padamu allah lain dihadapan-Ku'. Apabila ditinjau dari makna, dapat dikatakan bahwa kedua pernyataan dalam BB dan $\mathrm{BI}$ adalah sama. Perbedaan keduanya adalah adanya makna yang diimplisitkan dan juga dieksplisitkan. Pada BB jelas tertulis siapa yang memberi perintah dalam kalimat tersebut, yaitu Ahu do Jahowa Debatam ninna Debatanta yang artinya 'Akulah Tuhan Allahmu'. Pernyataan ini sangat tegas. Pada bagian selanjutnya baru ada bentuk larangan Ndang jadi marangkup Ahu bahenonmu Debatam 'jangan pernah kamu membuat yang sepeti Aku'. Dalam BI pernyataan ini kalau dinyatakan secara literal adalah 'Jangan pernah engkau membuat sesuatu yang seperti aku, Tuhan Allahmu'. Bentuk larangan ini jelas sangat tegas apabila dibandingkan dengan pernyataan dalam $\mathrm{BI}$. BI mengatakan 'Jangan ada padamu allah lain di hadapan-Ku'. Pada BI tidak dinyatakan siapa yang memberi larangan dan kenapa dilarang. Di dalam BB, jelas dinyatakan secara eksplisit melarang membuat sesuatu yang diperlakukan seperti Allah dan yang melarang adalah Allah sendiri.

Dari uraian di atas, dapat dilihat bahwa pada BB ketegasan terhadap larangan dinyatakan secara eksplisit, termasuk menyatakan siapa yang memberi larangan. Dalam $\mathrm{Bl}$ yang memberi larangan dinyatakan secara implisit. Tuhan Allah sebagai pihak yang memberi larangan tidak disebutkan secara eksplisit pada BI. BI hanya menyatakan jangan ada allah lain tanpa menyebutkan siapa yang melarang dan allah yang bagaimana yang dilarang tersebut. Meski tidak dinyatakan secara eksplisit tetapi pembaca telah memahami siapa yang memberi larangan tersebut. 


\section{Data 2: Hukum Kedua}

BB: Ndang jadi ganaonmu jala ndang jadi sumanonmu manang aha na di banuaginjang dohot na di banuatonga on ro di na di bagasan aek na di toru ni tano, ianggo tung gabe sisombaon manang siolon. (Patik Paduahon)

$\mathrm{Bl}$ : Jangan perbuat bagimu patung yang menyerupai apa pun yang ada di langit, atau yang ada di bumi atau yang ada di dalam air untuk disembah atau bertakwa kepadanya. (Hukum Kedua)

\section{Analisis Data 2 :}

Ganaonmu merupakan gabungan dari morfem gana + on $+\mathrm{mu}$ pada BB. Gana menurut Kamus Bahasa Batak online berarti tempa, bentuk, cipta, sumpah. Untuk konteks ini kata sumpah jelas bukan padanan dari kata gana, tetapi kata tempa, bentuk dan cipta tentunya kata yang dapat digunakan sebagai padanan dari kata gana. On + mu merupakan kata kerja yang menyatakan 'yang engkau perbuat'. Oleh karena itu ganaonmu mengandung makna 'yang engkau buat', 'yang engkau tempa', 'yang engkau ciptakan'. Jadi, Ndang jadi ganaonmu maksudnya adalah 'jangan pernah engkau membuat ...'

$\mathrm{BI}$ menggunakan kata 'patung' sebagai padanan kata ganaonmu. Menurut KBBI online 'patung' adalah "Tiruan bentuk orang, hewan, dan sebagainya dibuat (dipahat dan sebagainya) dari batu, kayu, dan sebagainya". Dari makna yang diperoleh dari KBBI dapat disimpulkan bahwa patung adalah tiruan bentuk orang maupun hewan yang dibuat manusia baik menggunakan batu, kayu atau material lainnya seperti, besi, tembaga perunggu dan lainnya. Manusia dilarang membentuk atau menciptakan sesuatu untuk disembah atau bertakwa kepadanya.

Di dalam BB selain mengunakan kata ganaonmu ada juga frasa yang menekankan makna larangan membuat tempaan atau ciptaan, yaitu kata sumanonmu. Kalau kita periksa pada kamus BB kata sumanonmu itu terdiri dari suman+on+mu. Suman artinya adalah menyerupai, tiru, cocok, layak, persis, serupa, sama dengan. Dengan ini dapat dikatakan bahwa kata ganaonmu dan sumanonmu mempunyai makna 'benda yang diciptakan' atau 'benda yang dipersamakan dengan'. Oleh karena itu dapat dikatakan pernyataan Ndang jadi ganaonmu jala ndang jadi sumanonmu adalah pernyataan larangan yang sangat keras dan tegas, selain tidak boleh ada yang diciptakan untuk disembah sebagai allah juga tidak boleh ada yang manusia perbuat yang menyerupai, yang kemudian disembah dan dituruti oleh manusia. Pada $\mathrm{BI}$, benda yang dilarang untuk dibentuk tersebut secara eksplisit menggunakan kata 'patung', sedang dalam BB tidak demikian. Dengan mengatakan 'patung' membuat pembaca lebih mudah memahaminya dibanding dengan pernyataan dalam BB, karena pada BB tidak mengatakan secara eksplisit benda bentukan tersebut.

Selanjutnya, larangan untuk membentuk atau membuat sesuatu untuk disembah tersebut pada kedua bahasa, BB dan BI sama-sama 
menguraikan untuk tidak membuat tiruan dari benda-benda yang ada di langit, di bumi dan di dalam air. Perbedaannya adalah pada BB mengeksplisitkan letak air, yaitu dibawah bumi, dengan mengatakan di bagasan aek na di toru ni tano. Dalam BI hanya dinyatakan dalam air saja tanpa menjelaskan air itu berada dimana. Namun, secara umum tanpa menyebut air yang berada di bawah bumi makna dari kalimat tersebut sudah merujuk pada mahluk yang hidup dalam air. Pada BB secara eksplisit menjelaskan air yang berada dimana, di bawah bumi. Hal ini dapat menghindarkan kekaburan makna, karena ada juga air buatan manusia yang tidak berada di bawah bumi.

Kemudian, dalam BB menggunakan frasa ianggo tung gabe sisombaon sebagai lanjutan dari larangan membuat tiruan allah. langgo ini berarti 'kalau'. Jadi, disini jelas melarang membuat tiruan allah 'kalau' dijadikan sesembahan, inilah yang dilarang, kalau untuk keperluan lain dari konteks ini dapat tidak dilarang. Hal ini tidak dinyatakan pada BI.

\section{Data 3: Hukum Ketiga}

BB: Ndang jadi dohonon goar ni Debata, ianggo so ture dalanna. Ai hona uhumNa do sogot angka na marsineang di goarNa. (Patik Patoluhon)

$\mathrm{BI}$ : Jangan menyebut nama TUHAN, Allahmu, dengan sembarangan, sebab TUHAN akan memandang bersalah orang yang menyebut nama-Nya dengan sembarangan. (Hukum Ketiga)

\section{Analisis Data 3:}

Kalimat Patik Ni Jahowa ke 3 ini apabila diterjemahkan secara literal ke dalam $\mathrm{BI}$ akan berbunyi 'Jangan pernah menyebut nama Tuhan kalau tidak benar tempatnya. Sebab kelak akan kena hukuman barang siapa yang secara sembarangan menyebut nama-Nya.' Frasa ianggo so ture dalanna adalah 'apabila tidak benar jalannya' maksudnya apabila menyebut nama Tuhan yang tidak pada tempatnya. Frasa ini sama maksudnya dengan sembarangan sebagaimana yang ditemukan pada hukum keempat $\mathrm{BI}$.

Kemudian Ai hona uhum-Na do sogot dalam BI dikatakan 'sebab kena hukuman-Nya besok' yang maksudnya adalah bagi orang yang secara sembarangan menyebut nama Tuhan maka dia akan kena hukuman Tuhan dikemudian hari. Pada bagian ini BB secara eksplisit menyebutkan akan kena hukuman dari Tuhan, sedang dalam $\mathrm{BI}$ hal ini diimplisitkan, BI melihat pada akibat pelanggraran, yaitu 'orang yang bersalah'. Dan lagi, BI tidak mengeksplisitkan bahwa yang melanggar larangan akan kena hukuman dan hukuman itu dari Tuhan sendiri. Pada $\mathrm{BI}$, tidak secara eksplisit menyinggung akan kena hukuman, tetapi menyatakannya dengan 'memandang bersalah'. Maka, soal hukuman dari Tuhan diimplisitkan pada BI. 


\section{Data 4: Hukum Keempat}

BB: Ingot hamu ma pabadiahon ari minggu i! Di na onom ari ma ula hamu nasa siulaonmu, alai anggo ari papituhon $i$, ari paradianan ni Jahowa Debatam do i. Ndang jadi ho mangula anggo di sadari $i$, manang anakmu pe manang borum, manang naposom lahilahi, manang naposom boruboru, ro di pinahanmu ro di pangisi ni huta ni halak pe na mangebati hutam. Ai di na onom ari do ditompa Debata langit dohot tano dohot laut dohot nasa isina; dung i maradian do Ibana di ari papituhon i. Dibahen i do umbahen na dipasupasu Debata Jahowa ari paradianan i jala diparbadiai. (Patik Paopathon)

$\mathrm{Bl}$ : Ingatlah dan kuduskanlah hari Sabat: enam hari lamanya engkau akan bekerja dan melakukan segala pekerjaanmu, tetapi hari ketujuh adalah hari Sabat TUHAN, Allahmu; maka jangan melakukan sesuatu pekerjaan, engkau atau anakmu laki-laki, atau anakmu perempuan, atau hambamu laki-laki, atau hambamu perempuan, atau hewanmu atau orang asing yang di tempat kediamanmu. Sebab enam hari lamanya TUHAN menjadikan langit dan bumi, laut dan segala isinya, dan la berhenti pada hari ketujuh; itulah sebabnya TUHAN memberkati hari Sabat dan menguduskannya. (Hukum Keempat)

\section{Analisis Data 4:}

Hukum keempat ini dikarenakan cukup panjang, maka akan diuraikan berdasarkan kalimat-kalimatnya.

a. Kalimat BB Ingot hamu ma pabadiahon ari minggu i! Di na onom ari ma ula hamu nasa siulaonmu, alai anggo ari papituhon i, ari paradianan ni Jahowa Debatam do $i$, dalam BI dinyatakan dengan 'Ingatlah dan kuduskanlah hari Sabat: enam hari lamanya engkau akan bekerja dan melakukan segala pekerjaanmu, tetapi hari ketujuh adalah hari Sabat TUHAN, Allahmu;' Untuk melihat lebih jelas terlebih dahulu kita lihat bagaimana kalimat BB dalam terjemahan literalnya. Demikian bunyinya: 'Kamu Ingatlah untuk menguduskan hari Minggu itu! Pada enam harilah kamu kerjakan semua pekerjaanmu, tetapi kalau hari ketujuh itu, hari berhentinya Tuhan Allahmu'.

Pada BB menggunakan hari ketujuh untuk hari dimana Tuhan berhenti dari pekerjaan-Nya. Pada $\mathrm{BI}$ hari ini dinyatakan dengan hari Sabat, dan dalam BB menggunakan kata hari Minggu. Pada Kamus Baru Bahasa Indonesia online kata sabat adalah hari ketujuh atau hari Tuhan beristirahat sesudah menciptakan alam semesta. Menurut kitab Taurat, hari ini biasanya dikhususkan untuk beribadah. Pada KBBI ini tidak dijelaskan hari sabat itu jatuh pada hari apa atau hari keberapa. Dikatakan demikian karena bagi sebagian pemahaman hari ketujuh itu adalah hari Sabtu. Akan tetapi hari ketujuh dipahami secara meluas pada masyarakat Batak dan Indonesia sebagai sebagai hari Minggu. 
Maka dapat dikatakan bahwa dalam BB secara eksplisit menyatakan hari yang harus dikuduskan adalah hari Minggu. Dalam BI menggunakan kata Sabat, dalam hal ini mungkin saja ada banyak orang yang tidak memahami apa yang dimaksud dengan hari Sabat. Untuk itu perlu pengetahuan lebih lanjut untuk memahami hari yang diharuskan untuk dikuduskan tersebut. Penggunaan hari Sabat dapat mengakibatkan ketidakjelasan.

b. Kalimat BB yang mengatakan Ndang jadi ho mangula anggo di sadari $i$, manang anakmu pe manang borum, manang naposom lahilahi, manang naposom boruboru, ro di pinahanmu ro di pangisi ni huta ni halak pe na mangebati hutam dalam $\mathrm{BI}$ dikatakan '...maka jangan melakukan sesuatu pekerjaan, engkau atau anakmu laki-laki, atau anakmu perempuan, atau hambamu laki-laki, atau hambamu perempuan, atau hewanmu atau orang asing yang di tempat kediamanmu'. Kalau kita perhatiakan satu per satu, kata mangula pada kamus BB online artinya adalah mencangkul, mengelola, bertani, bekerja, dan mengerjakan ladang. Kata yang paling sepadan dengan kata mangula pada konteks di atas adalah mencangkul sawah atau ladang atau juga bertani. Walau kata ini juga sepadan dengan bekerja tetapi yang merupakan makna primer dari kata ini adalah mencangkul tanah di ladang atau di sawah.

Dalam hal ini maka dapat dilihat bahwa BB mengeksplisitkan jenis pekerjaan yang dilarang. Paling tidak kata mangula sudah menggambarkan pekerjaan untuk mencari nafkah atau mencari uang. Dalam $\mathrm{BI}$ dinyatakan untuk tidak melakukan sesuatu pekerjaan. Pada konteks ini, tidak jelas pekerjaan apa yang dilarang tersebut, apakah semua pekerjaan tidak boleh dilakukan? Tentunya bukan demikian. Sebenarnya secara implisit yang dimaksud untuk tidak dilakukan adalah pekerjaan yang berkaitan dengan mencari uang. Tentunya pada hari Sabat itu orang tidak dilarang melakukan perjalanan, membersihkan rumah, atau pekerjaan lain yang tidak berkaitan dengan mencari uang.

c. Selanjutnya pada frasa ro di pinahanmu ro di pangisi ni huta ni halak pe na mangebati hutam. Terjemahan literal frasa ini adalah sebagai berikut: 'demikian juga hewanmu, demikian juga penduduk kota lain yang mengunjungi kampungmu/rumahmu. Dalam $\mathrm{BI}$ ro di menggunakan kata atau, seperti pada 'atau hewanmu atau orang asing yang di tempat kediamanmu'. Pada data ini hal penekanan makna itu terlihat jelas pada BB dengan menggunakan frasa ro di 'demikian juga', atau artinya bisa juga 'bahkan hewanmu', dan seterusnya. Oleh karena itu, pada BB dapat dilihat mengeksplisitkan ketegasan hukum ini. Pada konteks tersebut, apabila menggunakan kata manang yang artinya 'atau', sebenarnya kalimat tersebut tetap gramatikal. Tetapi penulis benarbenar ingin memberikan tekanan terhadap maksud dari hukum ini, bahkan hewan pun tidak boleh bekerja pada hari ketujuh ini, bukan hanya manusia yang tidak diperbolehkan bekerja. 
d. Kemudian ada perbedaan makna pada frasa BB pangisi ni huta ni halak pe na mangebati hutam yang dalam $\mathrm{BI}$ dinyatakan dengan 'orang asing yang di tempat kediamanmu'. Orang yang ada di tempat kediamam kita belun tentu orang asing. Memang, kata 'orang asing' disini dapat dipahami sebagai orang lain, tetapi kata orang asing ini masih tidak jelas. Akan tetapi, dalam BB hal ini sangat jelas. Pangisi ni huta ni halak pe na mangebati hutam artinya penduduk kampung orang lain yang datang mengunjungi kampungmu. Huta artinya adalah kampung, tetapi bisa juga yang dimaksud adalah rumah atau tempat tinggal. Jadi, frasa tersebut disini maksudnya adalah tamu, atau orang lain yang tidak serumah dengan kita. Maka oleh karena itu, pada konteks ini kita melihat bahwa BB mengeksplisitkan makna siapa orang yang dimaksudkannya.

\section{Data 5: Hukum Kelima}

BB: Ingkon pasangaphonmu do natorasmu asa martua ho, jala leleng mangolu di tano na nilehon ni Jahowa Debatam di ho. (Patik Palimahon)

BI: Hormatilah ayahmu dan ibumu, supaya lanjut umurmu di tanah yang diberikan TUHAN, Allahmu, kepadamu. (Hukum Kelima)

\section{Analisis Data 5:}

Hukum kelima pada BB apabila diterjemahkan secara literal ke dalam BI maka bunyinya adalah: 'Harus engkau muliakan orang tuamu supaya engkau beruntung atau bahagia, dan juga lama hidup di bumi yang diberikan Tuhan Allahmu kepadamu. Dengan kata lain dapat dikatakan 'Haruslah engkau memuliakan atau menghormati orang tuamu supaya bahagia hidupmu dan lanjut umurmu di tanah yang diberikan Tuhan Allahmu kepadamu. Bentuk perintah ini pada BB terlihat secara eksplisit, yaitu dengan adanya kata 'harus'. Pada BI dinyatakan dengan bentuk kalimat perintah namun keharusan itu tidak dinyatakan secara eksplisit.

Kemudian keeksplisitan dapat dilihat juga pada kata natoras pada BI. Kata natoras artinya adalah orang tua. Pada konteks di atas BB mengimplisitkan komponen makna dari kata orang tua, sedang dalam BI hal ini dinyatakan secara eksplisit, yaitu dengan menyebut 'ayahmu dan ibumu'. Kemudian pada kata martua. Menurut kamus BB martua berarti bahagia, beruntung dan juga sejahtera. Selain itu pada BB disebut juga panjang umur, yaitu pada frasa leleng mengolu yang secara harafiahnya adalah 'lama hidup'. Dalam BI kata martua tidak ada padanannya, yang ada hanya lanjut usia yang sepadan dengan leleng mangolu. Pada BI berarti pernyataan 'lanjut usia' secara implisit juga berarti bahagia. Maka dari uraian ini BB mengeksplistkan makna bahagia, beruntung, sejahtera dan diberkati yang merupakan makna kata martua tetapi dalam BI dinyatakan secara implisit pada frasa lanjut usia. 
Data 6: Hukum Kesepuluh

BB: Ndang jadi haliangan ni roham bagas ni donganmu, ndang jadi haliangan ni roham dongan saripe ni donganmu, manang naposona baoa manang naposona boruboru, manang lombuna manang hodana, manang dia pe ugasan ni donganmu. (Patik Pasampuluhon)

$\mathrm{Bl}$ : Jangan mengingini rumah sesamamu; jangan mengingini isterinya, atau hambanya laki-laki, atau hambanya perempuan, atau lembunya atau keledainya, atau apapun yang dipunyai sesamamu. (Hukum Kesepuluh)

\section{Analisis Data 6:}

Kata haliangi BB adalah mengingini dan kata ugasan adalah milik atau kepunyaan. Pada BB rasa mengingini yang tentunya bersumber dari hati seseorang dieksplisitkan dengan kosa kata roham 'hatimu'. Ndang jadi haliangan ni roham, yang artinya adalah 'jangan pernah diingini hatimu' . Pada $\mathrm{BI}$ hal ini diimplisitkan karena pada dasarnya keinginan terhadap sesuatu memang bersumber dari hati. Apakah hadirnya kata roham ini memang wajib? Ternyata dalam BB kata manghaliangi selalu diikuti kata roham kalau tidak kalimat tersebut menjadi tidak natural.

Kemudian pada kata dongan 'teman, kawan' yang dalam BI menggunakan kata 'sesama'. Kata dongan menunjukkan adanya kedekatan dari individu yang saling kenal, sedang pada kata 'sesama' tidak menunjukkankan adanya unsur saling kenal termasuk juga tidak ada unsur kedekatan. Kata 'sesama' hanya menyatakan orang lain yang sama-sama manusia. Pada kata ini, BB mengeksplisitkan kedekatan itu dengan jelas, maksudnya janganlah kita mengingini apa-apa yang dimililiki teman kita atau orang-orang yang dekat dengan kita. Karena pada orang yang dekat dengan kita yang dapat membuat kita mengetahui apa yang mereka miliki dan yang selanjutnya dapat menyebabkan kecemburuan atau ingin memiliki apa yang mereka miliki. Pada kata 'sesama', belum tentu kita mengetahui apa yang mereka miliki yang dapat membuat kita menginginkan apa yang mereka miliki. Pada data ini juga kita melihat kalau BB mengekplisitkan makna kedekatan atau pertemanan pada kata dongan dibanding dengan kata 'sesama' pada BI.

\section{Kesimpulan}

Dari 12 kasus makna implisit dan eksplisit yang ditemukan pada data yang digunakan, hanya satu kasus pada BI yang mengeksplisitkan komponen maknanya, yaitu pada kata frasa 'ayah dan ibu'. Ada empat kasus pada BB pengeksplisitan yang disebabkan struktur BB itu sendiri, yang dalam tabel disebut dengan wajib, yaitu Ndang jadi 'jangan pernah'; Unang ho... 'janganlah engkau/kamu ...'; dongan 'teman' dan manghaliangi roham 'diingini hatimu'. Kalimat tersebut akan tidak natural apabila tidak 
menggunakan kata-kata tersebut. Kemudian satu kasus BB yang mengimplisitkan maknanya, yaitu pada kata natoras 'orang tua', dan ini adalah bentuk yang natural pada BB. Selebihnya, bentuk eksplisit pada BB adalah untuk tujuan penekanan makna seperti pada dibagasan aek di toru ni tano 'di dalam air di bawah tanah'; ianggo tung gabe sisombaon 'kalau untuk disembah'; ro di 'bahkan; demikian juga'; pangisi ni huta ni halak 'penduduk kampung orang lain'. Hanya ada satu kasus yang mengeksplisitkan untuk tujuan menghindarkan ketidakjelasan, yaitu mangula 'bekerja (mencari nafkah). Hal ini dapat dilihat pada tabel berikut ini:

\begin{tabular}{|c|c|c|c|c|}
\hline No & $\begin{array}{ll}\text { Bhs } & \text { Batak/Makna } \\
\text { Literal } & \end{array}$ & $\begin{array}{l}\text { Bhs } \\
\text { Indonesia }\end{array}$ & $\begin{array}{l}\text { Keterangan } \\
\text { BB }\end{array}$ & $\begin{array}{l}\text { Keterang } \\
\text { an } \mathrm{BI}\end{array}$ \\
\hline 1 & $\begin{array}{l}\text { Ndang, jadi 'jangan } \\
\text { pernah' }\end{array}$ & jangan & Eksplisit/wajib & implisit \\
\hline 2 & $\begin{array}{l}\text { Unang } \underline{\text { ho.... 'janganlah }} \\
\text { engkau/kamu ...' }\end{array}$ & jangan & Eksplisit/wajib & implisit \\
\hline 3 & $\begin{array}{l}\text { Dibagasan aek di toru } \\
\text { ni tano 'di dalam air di } \\
\text { bawah tanah' }\end{array}$ & di dalam air & $\begin{array}{l}\text { Eksplisit } \\
\text { /penekanan } \\
\text { makna }\end{array}$ & implisit \\
\hline 4 & $\begin{array}{l}\text { langgo tung gabe } \\
\text { sisombaon 'kalau untuk } \\
\text { disembah' }\end{array}$ & $\begin{array}{l}\text { Untuk } \\
\text { disembah }\end{array}$ & $\begin{array}{l}\text { Eksplisit/penek } \\
\text { anan }\end{array}$ & implisit \\
\hline 5 & $\begin{array}{l}\text { Mangula 'bekerja } \\
\text { (mencari nafkah) }\end{array}$ & $\begin{array}{l}\text { Melakukan } \\
\text { sesuatu } \\
\text { pekerjaan }\end{array}$ & $\begin{array}{l}\text { Eksplisit/ } \\
\text { menjelaskan }\end{array}$ & implisit \\
\hline 6 & $\begin{array}{l}\text { Ingkon } \\
\text { pasanghonmu...'harus } \\
\text { kau hormati..' }\end{array}$ & Hormatilah.. & $\begin{array}{l}\text { Eksplisit/penek } \\
\text { anan }\end{array}$ & implisit \\
\hline 7 & $\begin{array}{ll}\text { Natorasmu } & \text { 'orang } \\
\text { tuamu' }\end{array}$ & $\begin{array}{l}\text { Ayah dan } \\
\text { ibumu }\end{array}$ & $\begin{array}{l}\text { Implisit/pilihan } \\
\text { penerjemah }\end{array}$ & $\begin{array}{l}\text { Ekplisit/p } \\
\text { enekana } \\
n\end{array}$ \\
\hline 8 & $\begin{array}{l}\text { Ro di 'bahkan; } \\
\text { demikian juga' }\end{array}$ & atau & $\begin{array}{l}\text { Eksplisit/penek } \\
\text { anan makna }\end{array}$ & implisit \\
\hline 9 & $\begin{array}{l}\text { Pangisi ni huta ni halak } \\
\text { 'penduduk kampung } \\
\text { orang lain' }\end{array}$ & Orang asing & $\begin{array}{l}\text { Eksplisit } \\
\text { /penekanan } \\
\text { makna }\end{array}$ & implisit \\
\hline 10 & $\begin{array}{l}\text { Martua 'bahagia, } \\
\text { beruntung, sejahtera' }\end{array}$ & - & $\begin{array}{l}\text { Eksplisit/penek } \\
\text { anan makna }\end{array}$ & - \\
\hline 11 & Dongan 'teman' & sesama & Eksplisit/wajib & implisit \\
\hline 12 & $\begin{array}{l}\text { Manghaliangi } \\
\text { 'diingini hatimu' }\end{array}$ & 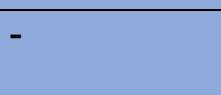 & Eksplisit/wajib & implisit \\
\hline
\end{tabular}

Kalau dilihat pada tabel ini, BB lebih sering mengeksplisitkan maknanya dengan berbagai tujuan, apakah hal ini ada kaitannya dengan karakter masyarakat penutur yang akan kurang paham apabila tidak 
dieksplisitkan?,Hal ini belum diketahui secara pasti. Untuk mengetahui hal ini diperlukan penelitian lebih lanjut terhadap penutur bahasa Batak.

Kajian ini merupakan kajian awal, diharapkan dapat dilakukan kajian yang lebih mendalam yang menggunakan data yang lebih luas lagi untuk mengetahui karakter bahasa Batak Toba dan mengenali makna implisit dan makna eksplisit dalam penerjemahan.

\section{Kepustakaan}

Hoed, B.H. (2006). Penerjemahan dan Kebudayaan. Jakarta: Pustaka Jaya.

Pusat Bahasa Departemen Pendidikan Nasional. (2005). Kamus Besar Bahasa Indonesia.Edisi ke-3. Jakarta: Balai Pustaka.

Cadford, J.C. (1965). A Linguistic Theory of Translation. London: Oxford University Press.

Halliday, MAK dan R. Hasan. (1976). Cohesion in English. London: Longman.

Hatim,B.dan Mason, I. (1997). The Translator as Communicator. London: Routledge.

Hatim, B. (2001). Teaching and Researching Translation. London: Longman.

Larson, Mildred L. (1984). Meaning-based Translation: A Guide to Crosslanguage Equivalence. London: University of America, Inc.

Leech, G. and Svartvik, J. (1994). A Communicative Grammar of English.2ndedition.London: Longman.

Machali, R. (1998). Redefining Textual Equivalence in Translation. Jakarta: The Translation Centre, Faculty of Arts -the University of Indonesia.

Newmark, P. (1988). Approaches to Translation. Hertforshire: Prentice Hall International (UK) Limited.

Nida, E. (1956). Bible Translating. In Brower,R.A. ed. On translation. pp.1113. Harvard: Harvard University Press.

Nida, E.A dan Taber, C.R. (1974). The Theory and Practice of Translation. Leiden: E.J. Bril

Sinclair, J. (ed.). (1988). Collins Cobuild Essential Dictionary: Helping learners with real English. London: William Collins \& Co Ltd.Summers, D. (ed.). (1992). Longman Dictionary of Language and Culture. Essex: Longman UKLimited.

http://hkbpgaolrigs.blogspot.com/2013/06/patik-ni-debata-nasampuluidohot.html

http://seputarhkbp.blogspot.com/p/katekhimus-kecil-martin-luther-bab-i.html

(https://id.wikipedia.org/wiki/Suku Batak).

https://www.kamusbatak.com/

http://hkbpgaolrigs.blogspot.com/2013/06/patik-ni-debata-nasampului-

dohot.html 


\section{Lampiran}

\section{PATIK NI DEBATA NASAMPULUI DOHOT LAPATANNA}

\section{KATEKHIMUS na METMET \\ MARTIN LUTHER}

\section{BINDU PARJOLO}

P ATIK NI DEBATA

Patik Parjolo

Ahu do Jahowa DebataM, ninna Debatanta. Ndang jadi marangkup Ahu bahenonmu Debatam.

\section{Patik Paduahon}

Ndang jadi ganaonmu jala ndang jadi sumanonmu manang aha na di banuaginjang dohot na di banuatonga on ro di na di bagasan aek na

di toru ni tano, ianggo tung gabe sisombaon manang siolon.

\section{Patik Patoluhon}

Ndang jadi dohonon goar ni Debata, ianggo so ture dalanna. Ai hona uhumNa do sogot angka na marsineang di goarNa.

\section{Patik Paopathon}

Ingot hamu ma pabadiahon ari minggu i! Di na onom ari ma ula hamu nasa siulaonmu, alai anggo ari papituhon i, ari paradianan ni Jahowa

Debatam do i. Ndang jadi ho mangula anggo di sadari i, manang

anakmu pe manang borum, manang naposom lahilahi, manang naposom boruboru, ro di pinahanmu ro di pangisi ni huta ni halak pe

na mangebati hutam. Ai di na onom ari do ditompa Debata langit dohot tano dohot laut dohot nasa isina; dung i maradian do lbana di ari papituhon i. Dibahen i do umbahen na dipasupasu Debata Jahowa ari paradianan i jala diparbadiai.

\section{Patik Palimahon}

Ingkon pasangaphonmu do natorasmu asa martua ho, jala leleng mangolu di tano na nilehon ni Jahowa Debatam di ho.

Patik Paonomhon

Unang ho mamunu

Patik Papituhon

Unang ho mangalangkup 


\section{Patik Paualuhon \\ Unang ho manangko}

\section{Patik Pasiahon}

Unang ho olo manghatindanghon hata na so tutu maralohon dongan jolma.

\section{Patik Pasampuluhon}

Ndang jadi haliangan ni rohan bagas ni donganmu, ndang jadi haliangan ni roham dongan saripe ni donganmu, manang naposona baoa manang naposona boruboru, manang lombuna manang hodana, manang dia pe ugasan ni donganmu.

http://seputarhkbp.blogspot.com/p/katekhimus-kecil-martin-luther-bab-i.html

\section{KATEKHIMUS KECIL}

KATEKHIMUS KECIL

MARTIN LUTHER

\section{Dasa Titah \\ Titah Pertama}

Akulah Tuhan Allahmu, seru Tuhan kita. Tidak boleh ada allah lain, kecuali Aku.

Titah Kedua

Jangan perbuat bagimu patung yang menyerupai apapun, yang ada di langit, atau yang ada di bumi, atau yang ada di dalam air untuk disembah atau bertakwa kepadanya.

\section{Titah Ketiga}

Jangan menyebut nama Tuhan Allah dengan sembarangan, karena Allah akan menghukum orang yang menyalah-gunakan namaNya.

\section{Titah Keempat :}

Ingat dan sucikanlah hari yang dikuduskan itu. Lakukanlah segala pekerjaanmu di dalam enam hari; tetapi pada hari yang ketujuh ialah Sabat bagi Allah Tuhanmu. Engkau tidak boleh bekerja pada hari itu, juga anakmu laki-laki atau perempuan, pembantumu laki-laki atau perempuan, ternakmu atau orang lain yang berada di tempat 
kediamanmu. Sebab Allah menciptakan langit dan bumi dan segala isinya di dalam enam hari. Kemudian la beristirahat pada hari yang

ketujuh. Itulah sebabnya Allah memberkati hari itu dan menguduskannya.

Titah Kelima

Hormatilah Bapa dan Ibumu agar engkau berbahagia dan lanjut umurmu di bumi yang diberikan Allah kepadamu.

Titah keenam

Jangan engkau membunuh!

\author{
Titah Ketujuh \\ Jangan engkau berzinah! \\ Titah Kedelapan \\ Jangan engkau mencuri
}

\title{
Titah Kesembilan \\ Jangan engkau berdusta!
}

Titah Kesepuluh

Jangan engkau mendambakan akan rumah sesamamu. Jangan engkau mendambakan akan istrinya, atau pembantunya laki-laki maupun perempuan, ternaknya atau segala sesuatu milik mereka. 